TITLE:

\title{
ON TREBIUS LONGICAUDATUS SHIINO (COPEPODA : CALIGOIDA) FOUND ON THE FETUS OF SQUATINA NEBULOSA REGAN
}

AUTHOR(S):

Shiino, Sueo M.

CITATION:

Shiino, SUeo M.. ON TREBIUS LONGICAUDATUS SHIINO (COPEPODA: CALIGOIDA) FOUND ON THE FETUS OF SQUATINA NEBULOSA REGAN. PUBLICATIONS OF THE SETO MARINE BIOLOGICAL LABORATORY 1963, 11(2): 403-407

\section{ISSUE DATE:}

1963-12-31

URL:

http://hdl.handle.net/2433/175334

RIGHT: 


\title{
ON TREBIUS LONGICAUDATUS SHINO (COPEPODA : CALIGOIDA) \\ FOUND ON THE FETUS OF SQUATINA \\ NEBULOSA REGAN ${ }^{1)}$
}

\author{
Sueo M. SHIINO \\ Zoological Institute, Faculty of Fisheries, \\ Prefectural University of Mie
}

With 2 Text-figures

Trebius longicaudatus SHINo is a caligoid copepod parasitic on Squatina nebulosa REgan. Among the members of the genus Trebius this species, which was originally found in the buccal cavity or on the body surface of host, is characterized above all by the possession of much elongate abdomen which is nearly twice as long as the carapace, occupying less than half the length of the entire body.

The year before last, Dr. T. Tokıoka of Seto Marine Biological Laboratory presented me with a number of specimens found by Dr. E. Harada on the body of the fetuses of the same host species caught off Shirahama. They were remarkable not only for their unusual location on the host body but also for an extraordinary elongation of their abdomen which reaches several times the length of the rest of body. In spite of these, a thorough investigation on their morphology demonstrated that they belong to the known species same as that found on the exterior of the host. I feel, therefore, the necessity of giving a short account as regards the proportions of the body regions and some minor points that escaped my notice when I gave the definition of the species.

Before going farther, I wish to express my obligation to Dr. T. TokiokA who kindly presented the material to me.

\section{Trebius longicaudatus SHINO}

(Figs. 1 and 2)

ShINO 1954: 247-251, Figs, 1-2.

Occurrence: 11 females; 9 of them carrying egg strings. On the body sur-

1) Contributions from the Seto Marine Biological Laboratory, No. .

Publ. Seto Mar. Biol. Lab., XI (2), 1963. (Article 24) 
face of the fetuses of Squatina nebulosa REGAN caught off Shirahama, Wakayama Prefecture, by Mr. Inagaki and Dr. Harada, May 4, 1961.

Female: Body white in alcohol, without pigment spots; egg strings yellowish. Carapace more or less convex above, genital segment somewhat swollen dorsiventrally; abdomen cylindrical, extraordinarily elongate and with one or two constrictions, though segmental boundaries hardly discernible.

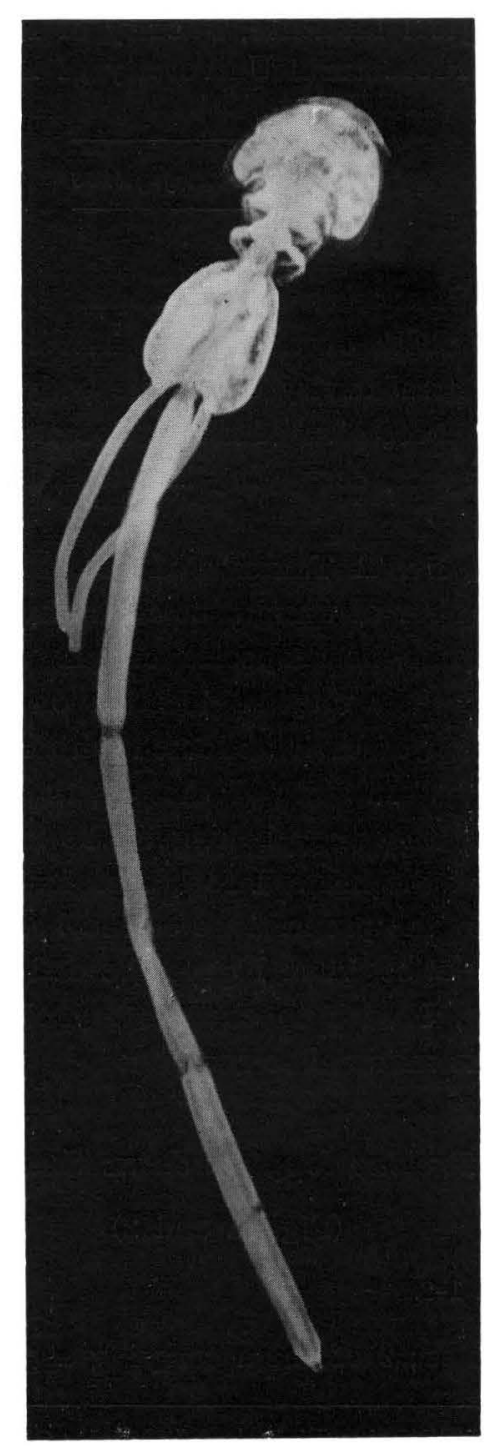

Fig. 1. Trebius longicaudatus SHInNo, female, parasitic on the fetus of Squatina nebulosa REGAN. $\times 4.7$ 
Except for an unusual prolongation of the abdomen, the constitution of the rest of body and the detail in the structure of appendages are in strict accord with those of the holotype. Measurements of the body regions taken from 9 females with perfect abdomen are listed in the table inserted here. They are represented by 12.5 times the real length unless otherwise indicated.

\begin{tabular}{|c|c|c|c|c|c|c|c|}
\hline $\begin{array}{l}\text { Carapace } \\
\text { plus 4th } \\
\text { segment }\end{array}$ & $\begin{array}{c}\text { Genital } \\
\text { segment }\end{array}$ & $\begin{array}{c}\text { Length } \\
\text { of } \\
\text { abdomen }\end{array}$ & $\begin{array}{c}\text { Total } \\
\text { length }\end{array}$ & $\begin{array}{l}\text { Real } \\
\text { body } \\
\text { length }\end{array}$ & $\begin{array}{l}\text { Length } \\
\text { of egg } \\
\text { tube }\end{array}$ & $\begin{array}{l}\text { Real } \\
\text { length } \\
\text { of egg } \\
\text { tube }\end{array}$ & $\begin{array}{c}\text { Length of abdomen } \\
\text { Length of carapace plus } \\
\text { 4th segment }\end{array}$ \\
\hline $44 \times 38$ & $46 \times 31$ & 277 & 366 & $29.4 \mathrm{~mm}$ & 71 & $5.7 \mathrm{~mm}$ & 6.3 \\
$46 \times 31$ & $35 \times 21$ & 161 & 242 & $19.4 \mathrm{~mm}$ & 0 & 0 & 3.5 \\
$46 \times 36$ & $48 \times 31$ & 268 & 362 & $29.0 \mathrm{~mm}$ & 184 & $14.8 \mathrm{~mm}$ & 5.8 \\
$46 \times 37$ & $43 \times 29$ & 271 & 360 & $28.8 \mathrm{~mm}$ & 73 & $5.8 \mathrm{~mm}$ & 5.9 \\
$47 \times 34$ & $50 \times 33$ & 323 & 420 & $33.6 \mathrm{~mm}$ & 215 & $17.2 \mathrm{~mm}$ & 6.9 \\
$47 \times 38$ & $32 \times 20$ & 97 & 176 & $14.1 \mathrm{~mm}$ & 0 & 0 & 2.1 \\
$47 \times 39$ & $50 \times 35$ & 363 & 460 & $36.8 \mathrm{~mm}$ & 130 & $10.4 \mathrm{~mm}$ & 7.7 \\
$48 \times 39$ & $50 \times 33$ & 334 & 432 & $34.6 \mathrm{~mm}$ & 194 & $15.3 \mathrm{~mm}$ & 7.0 \\
$50 \times 36$ & $55 \times 36$ & 425 & 530 & $42.5 \mathrm{~mm}$ & 201 & $16.8 \mathrm{~mm}$ & 8.5 \\
\hline
\end{tabular}

In the holotype the ratio between the length of the abdomen and that of the carapace plus the fourth segment attains merely to 1.26. In the longest female of the present lot of specimens the abdomen reaches 8.5 times the rest of body and even in the shortest one it exceeds twice. It is of uniform width throughout its entire length and has one or two slight constrictions, which scarcely show any segmental border on the surface. Owing to the preservation in a narrow vial, the abdomen is folded once or twice, leaving faint transverse furrows behind, which are liable to be mistaken for the true lines of articulation. The genital segment has three papillae on the caudal margin on each side of the base of abdomen. The internal papilla which is triangularly pointed lies just above the attachment of egg string and the others are located a little more laterally and ventrally and invisible from above.

The distal segment of the first antenna is not biarticulated. The second maxilla has the inner accessory branch much more reduced than in the holotype. The sternal furca possesses the branches somewhat more divergent. The outer spines on the exopodite joints of the second leg are associated at their bases each with a more or less broad membraneous lamina with parallel striation on the surface. Two short outer spines on the third joint of the same exopodite are doubly fringed by fine hairs. The second exopodite joint of the succeeding leg is hairy on the inner margin instead of having two rows of cirri. Distal two joints of the exopodite of the same leg have a narrow pectinated rim on the outer margin. The corresponding joints of the exopodite in the fourth leg are also furnished with an outer pectinate rim. In other points as in the holotype. 


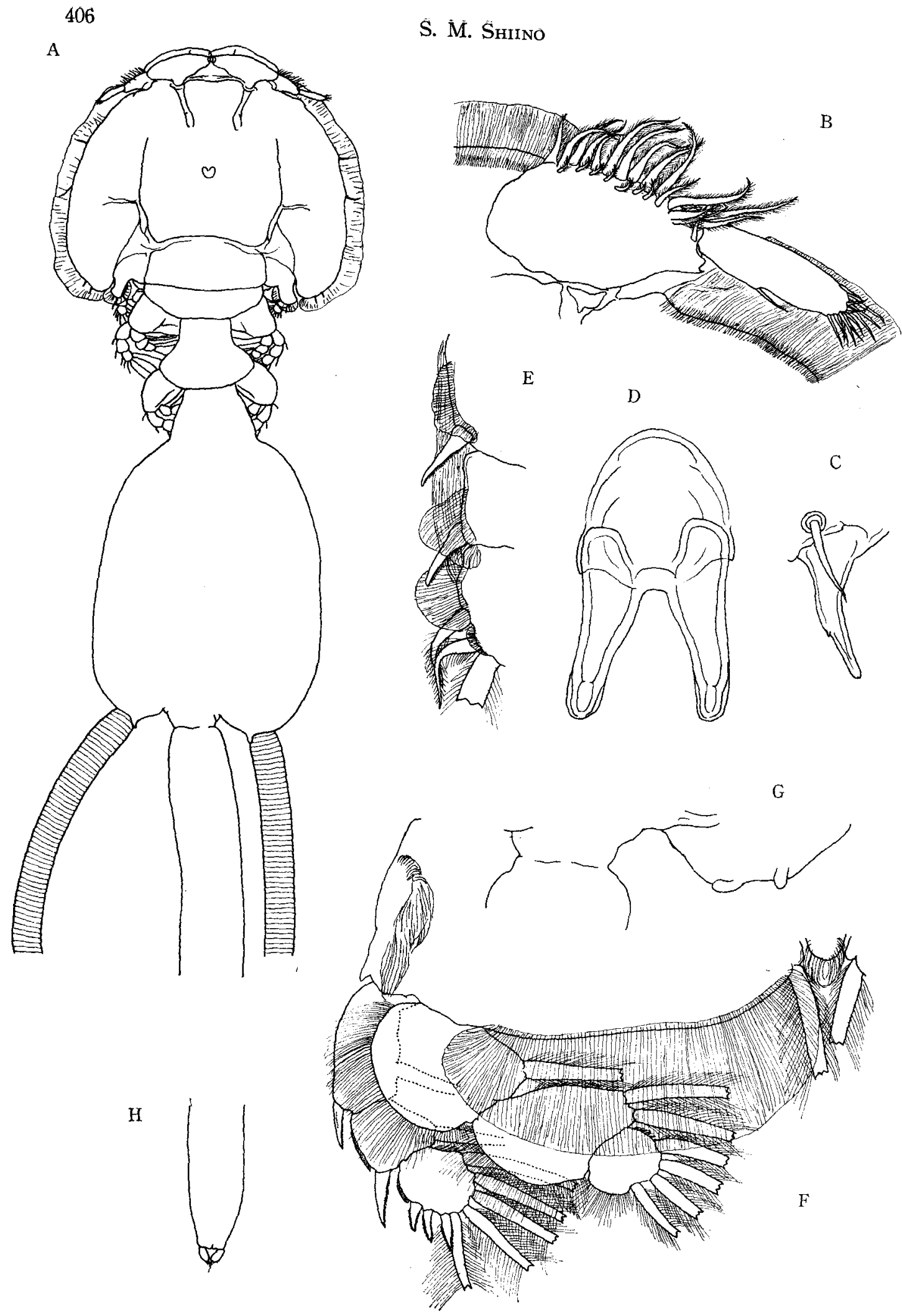


Remarks: The species is known only from the female. A plausible explanation for an excessive prolongation of the abdomen may be sought in the respiratory adaptation of the copepods living in such an unusual environment as the interior of the host cloaca. Since anal respiration is known occasionally to be the case with the Order Copepoda, it is presumed that those internal parasites may be able to get access to fresh respiratory water by extruding the tip of long abdomen at times from the host anus.

\section{LITERATURE}

ShIINo, S. M., 1954. Copepods parasitic on Japanese fishes. 2, On two new species of the family Trebidae. Rep. Fac. Fish., Pref. Univ. Mie, 1 : 247-259.

Fig. 2. Trebius longicaudatus SHIINo, female, parasitic on the fetus of Squatina nebulosa REGAN. A, dorsal view ; B, first antenna ; $C$, second maxilla ; $D$, sternal furca ; $\mathrm{E}$, outer margin of exopodite of second leg; F, third leg; G, caudo-lateral angle of genital segment, ventral view; $\mathrm{H}$, caudal end of abdomen.

$\mathrm{A}, \mathrm{H} \times 12, \mathrm{~B}, \mathrm{C}, \mathrm{F} \times 82, \mathrm{D}, \mathrm{E} \times 170, \mathrm{G} \times 42$. 